\title{
The Iddah Period as a Reason for Cancellation of Marriage
}

\author{
Rahayu Mulia Romadoni \\ Airlangga University, Indonesia \\ rahayu.mulia.romadoni-2017@fh.unair.ac.id
}

\begin{abstract}
The iddah period is a waiting period that applies to a woman whose marriage is broken legally through divorce or physically through the death of a husband. Any woman who has not had a prior marriage must observe the iddah period. As one of the legal conditions of marriage, failure to complete the iddah period can result in the cancellation of any secondary marriages. In this study, judges release a verdict in accordance with the laws and legislation of Indonesia, namely Law No. 1 of 1974 on Marriage and a compliation of Islamic law found in Al-Qur'an and Hadith. This article uses legal research based on positive laws including judicial decision. This study concluded that if a marriage is prohibited for a failure to satisfy the condition of iddah, that marriage must be cancelled. This article employs statute and conceptual approaches to legal research, as well as case study methodology, with the aim of departing from the views and doctrines that develop in law in order to build a legal argument that addresses legal issues. Analyzing the Decision of the Mojokerto Religious Court Number 1365/Pdt.G/2014/PA.Mr, this study argues that prospective spouses are responsible for awareness of their prospective partners' marriage eligibility and fulfillment of all requirements, material and formal, clearly stipulated in state and religious law.
\end{abstract}

KEYWORDS: Iddah, Islamic Law, Marriage Cancellation.

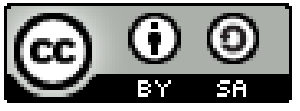

Copyright $₫ 2019$ by Author(s)

This work is licensed under a Creative Commons Attribution-ShareAlike 4.0 International License. All writings published in this journal are personal views of the authors and do not represent the views of this journal and the author's affiliated institutions.

\section{HOW TO CITE:}

Romadoni, Rahayu Mulia. "The Iddah Period as a Reason for Cancellation of Marriage" (2019) 6:2 Lentera Hukum 235-252.

Submitted: June 04, 2019 Revised: June 09, 2019 Accepted: June 10, 2019 


\section{INTRODUCTION}

Marriage is one form of Islamic worship in which individuals choose one another as a lifelong partner. Marriage law is part of the teachings of Islam that must be obeyed and carried out according to the provisions of Al-Quran and Sunnah Rosul. In the Islamic tradition, marriage is a blessing for those involved, especially in terms of worship and child-rearing. If marriage is understood only as a bond or civil contract, the sanctity of marriage as a form and instrument of social worship will be devalued. Furthermore, AlQuran states that living in pairs, matched, is the instinct of God's creatures, including humans. realize the sanctity of marriage as a worship instrument and act proscribed by Allah, marriage is regulated by Islamic marriage law. ${ }^{1}$ More specifically, marriage law determines and regulates the procedures of family life, and as a result, the core of people's lives. $^{2}$

Marriage in Indonesia is regulated in Law No. 1 of 1974 on Marriage, and Instruction of President No. 11 in 1999 on the Compilation of Islamic Law and Customary Law. According to Law No. 1 of 1974 on Marriage, marriage is defined as follows: ${ }^{3}$

1. The phrase "a man with a woman" is used, specifying that marriage is only between different genders. Therefore, the law inherently rejects same-sex marriage.

2. The expression "husband and wife" is used, implyingthat marriage is the meeting of two different genders in a household to fulfill their prescribed duties, as opposed tosimply "living together."

3. It is stated that marriage is based on the One and Only God. The law reflects the role of marriage as a religious event in Islam, carried out to fulfill religious orders.

4. With tangible and intangible ties, marriage implies a close relationship between husband and wife which involves feelings of affection, the ability to get along, and even joking familiarly in a happy and cheerful atmosphere. Spouses must complement each other while addressing each other's needs, both physical and mental. In this respect, the aim of marriage is to form a happy and eternal household.

In contrast, marriage according to the Compilation of Islamic Law Article 2 reads:

"Marriage according to Islam is... a very strong contract or mitssaqan ghalidzan to obey

Allah's commands and carry it out is worship.'

Article 3 of the Compilation of Islamic Law the purpose of marriage is to realize the domestic life of sakinah, mawaddah and warahmah. The definition of mawaddah is love between husband and wife, including mutual sexual needs. From mawaddah arises a sense of courtesy or mutual support (rahmah) and serenity (sakinah).

\footnotetext{
Ahmad Rofiq, Hukum Perdata Islam di Indonesia (Jakarta: Rajawali Persada, 2015) at 53.

Abd Rahman Ghazaly, Fiqh Munakahat (Jakarta: Prenada Media, 2003) at 13.

Ahmad Azhar Basyir, Hukum Perkawinan Islam (Yogyakarta: UII Press, 1990).
} 
Islamic philosopher Imam Ghazali categorizes the purpose and benefits of marriage into five motivating themes. First, marriage is to produce legitimate offspring that will themselves produce offspring and develop human tribes. ${ }^{4}$ Second, it is to meet the instinctive demands of human life. ${ }^{5}$ Third, it is to maintain order among humans by preventing crime and damage. ${ }^{6}$ Fourth, it is to establish and regulate households on the basis of love and affection, thereby creating a foundation for larger communities. ${ }^{7}$ The last, marriage is to grow sincerity trying to find halal sustenance, and enlarging a sense of responsibility. ${ }^{8}$

On the basis of the many contexts which shape the definition of marriage, the meaning of 'marriage' itself can be divided into three perspectives. First, legal perspective which puts simply that marriage is an agreement. ${ }^{9}$ The legal perspective also provides the opportunity to classify marriage as an agreement, rather than a social or religious practice, as marital arrangements can be arranged in advance. So, too, is there a method of breaking marital ties that havebeen arranged in advance, namely through talaq, fasakh, syaqaq and so on. Second, social perspective in which in the society of every nation, a common assessment is found, that people who have a family or used to have a family, have more valued position than those who do not marry. ${ }^{10}$ The social perspective emphasizes an intersocietal perception of people who are married or have a family as more valuable than those who are not. Third, religious perspective in which in many religions, marriage is considered a holy symbol. Marriage ceremonies are holy ceremonies in which both parties are linked as spouses. In the Islamic tradition, marriage is an invitation to join as life partners by invoking the name Allah. ${ }^{11}$

Based on Law Number 1 of 1974 on Marriage, there are two kinds of marital conditions.Material requirements, also known as subjective conditions, are conditions inherent in or belonging to each party to the marriage. Formal requirements, or objective conditions, are those embedded in the procedure for conducting marriage according to religious and secular law. ${ }^{12}$ The material requirements of marriage are regulated in articles 6-11 of Law No. 1 of 1974 on Marriage. In short, the requirements are as follows: $:^{13}$

a. Marriage must be based on the agreement of the two prospective parties (Article 6 paragraph (1));

\footnotetext{
Mohammad Idris Ramulyo, Hukum Perkawinan Islam, Suatu Analisis UU No.l Tahun 1974 dan Kompilasi Hukum Islam (Jakarta: Bumi Aksara, 1996).

Ibid.

Ibid.

Ibid.

Ibid.

Ahmad Rofiq, supra note 1 at 58.

Ibid.

Ibid.

Abdulkadir Muhammad, Hukum Perdata Indonesia (Bandung: Citra Aditya Bakti, 2000) at 36.

13 Wibowo T Tunardi, "Syarat-Syarat Sahnya Suatu Perkawinan", (3 May 2019), online: J Huk 〈http://www.jurnalhukum.com/syarat-syarat-sahnya-suatu-perkawinan/`.
} 
b. Men must be at least 19 years old and women must be at least 16 years old (Article 7 paragraph (1));

c. Permission must be granted from each party's parents, except in certain cases, such as prospective brides aged 21 years or more, or in the event of dispensation from the Religious Court if marriage candidate age is less than 19 and 16 years, respectively (Article 6 paragraph (2) and Article 7 paragraph (2));

d. Not violating prohibitions on marriage as stipulated in Article 8, including marriage between two people:

1) Having blood in a straight line down or up.

2) Having blood in a horizontal line, such as siblings, between one person and the parents, and between one person and their grandmother's brother.

3) With a good relationship, such as in-laws or stepparents and their children

4) Those with a specific relationship, namely breastfeeding parents, breastfeeding children, breastfeeding siblings and aunts.

5) Related through the connection of one's wife, in the case of a woman who marries more than once.

6) Having a relationship which by religion or other applicable regulations is prohibited from marrying.

e. Not bound by another marriage;

f. Husbands and wives who have divorced each other twice cannot remarry each other, unless the laws of each religion and belief of the people concerned do not determine otherwise (Article 10);

g. A woman whose marriage ends must complete a waiting (iddah) period before remarrying (Article 11).

Marriage requirements are further regulated in articles 3-13 of Government Ordinance of the Republic of Indonesia No. 9 of 1975 on the Implementation of Law No. 1 of 1974 on Marriage. In brief, these formal requirements can be described as follows: ${ }^{14}$

1. Everyone who is going to have a marriage must notify his will to the Marriage Recording Officer where the marriage will take place at least 10 days before the marriage takes place. Notification can be made orally or in writing by the prospective spouses, their parents, or a representative of the couple. The notification includes name, age, religion, and place of residence of the bride and groom (Article 3-5);

2. After the notification is received by the Employer of Marriage Registration they are examined, and an official determines whether the couple has satisfied the marriage requirements or not. The results of the study are written in a special list for this matter (Article 6-7);

3. If all the conditions are met, an announcement is made and signed by the Marriage Recording Officer, which includes:

a. Name, age, religion, and occupation of the bride and groom.

14 "Syarat-Syarat Perkawinan", (3 May 2019), online: Syarat-Syarat Perkawinan 〈http://pkbh.uad.ac.id/syarat-syarat-perkawinan/〉. 
b. The date, time, and location at which the marriage will take place (chapters 8-9);

4. Only marriage taking place after the tenth day is carried out according to the laws of each religion and its beliefs. After the two prospective spouses sign a marriage certificate before a Recording Officer and two witnesses, the marriage is officially registered. The marriage certificate is made in duplicate, one for the Record Officer and the other for the Court Clerk. Both parties to the marriage are given a quotation of a marriage certificate (chapters 10-13).

Article 14 in the Compilation of Islamic Law specifies who must be present in carrying out a marriage: ${ }^{15}$
a. Future husband;
b. Future wife;
c. Guardian of marriage;
d. Two witnesses; and
e. Ijab and Kabul

Article 2 paragraph (1) of Law Number 1 of 1974 on Marriage states that marriage is legal if it is carried out according to the law of each religion and its belief, therefore religion is the basic legitimacy-establishing element. In order for a marriage to be considered legitimate, it must be registered in accordance with formal requirements established by law, as stipulated in Article 2 paragraph (2) of Law Number 1 of 1974 on Marriage. The process of marriage registration is differentiated according to the religion recognized by legislation. Marriage registration is further regulated in chapter 2 Article 2 of Government Ordinance of the Republic of Indonesia No. 9 of 1975 on Implementation of Law No. 1 of 1974 on Marriage, which states that for those who are Muslim, amarriage must be registered at the Office of Religious Affairs, while for those who are not Muslim, marriage must be registered with the Civil Registration Office. Marriage registration grants a marriage legal force should problems arise later. Particulalry, in the religious perspective of marriage, marriage must be maintained properly so that its purpose, to form a happy and eternal household, can be realized. Yet the destination of marriage runs aground on the road. Several factors can cause a marriage to end. In Article 38 of the Marriage Law, it is explained that a marriage can be terminated due to death, divorce, or the decision of a court.

The termination of marriage as a result of death is very literal; the death of either husband or wife results in the legal termination of the marriage. In the case of death, surviving parties may remarry if all conditions specified by the applicable regulatory laws are fulfilled accordingly. ${ }^{16}$ Likewise, in the event of divorce, the wife must meet the requirements determined by applicable legislation, more specifically the period of iddah. In this case, the wife must wait for the specified term to be finished prior to remarrying. An iddah period is not required for men prior to remarriage. The iddah

15 Sayuti Thalib, Huku Kekeluargaan Indonesia (Jakarta: Rajagrafindo, 2000).

16 Lili Rasjidi, Perkawinan dan Perceraian di Malaysia dan Indonesia (Bandung: Remaja Posdakarya, 1992). 
period is used to find out if the woman who was left behind by the husband is pregnant or not. ${ }^{17}$ For women who are known to be pregnant after divorce, they must wait until delivery of the child for the iddah period to be completed. If the woman is not pregnant, the duration of iddah is determined according to the applicable laws and regulations. Women who have never had intercourse (qobla al dukhul) but then divorced can remarry without completing an iddah period. This is regulated in Article 11 of the Marriage Law in conjunction with Article 153 Compilation of Islamic Law. Marriage can be carried out if the conditions for carrying out a marriage are fulfilled and there is no violation of marriage restrictions or requirements. If a marriage has occurred despite a failure to satisfy all requirements, and the failure is only known by the prospective spouses, that marriage is legally prohibited and as a result can be canceled.

\section{CANCELLATION DUE TO MARRIAGE BEFORE FINISHING IDDAH}

The existence of marriage termination can be due to two things: (1) death and (2) divorce settled in court. Both have the same effect on women, whose divorce settlement must include iddah, as clearly stipulated in the Compilation of Islamic Law. ${ }^{18}$ In the Indonesian Dictionary the word divorce comes from the word "cerai" gets the prefix "per" and the suffix "an," which altogether (perceraian) means to release the bond. Divorce in fiqh is called talak, which comes from the Arabic thalak or al ithlaq, meaning to let go and leave. In Shari'ah Islam talak is interpreted as releasing or ending something. ${ }^{19}$ According to Agoes Dariyo's Psikologi Pembangunan Dewasa Muda, divorce is the culmination of various problems that have accumulated over a period of time and the last resort that must be taken when the marriage relationship cannot be maintained anymore. ${ }^{20}$ Amato, Olson \& DeFrain likewise define divorce as an event of official separation between married couples who are determined to no longer carry out their duties as husband and wife. ${ }^{21}$

Semantically, iddah means a time or grace period. ${ }^{22}$ Iddahis an Arabic word which comes from the word adda-ya'uddu-idatan. The plural of iddah is iddad, meaning"count." This word is used for the waiting period following the end of a marriage because in those days the woman who was waiting counted the passage of time. ${ }^{23}$ The function of the iddah period is to know whether the female party in a divorce is pregnant, because

17 Rosidin, "Masa Iddah Wanita Hamil yang Ditinggal Wafat Suaminya Menurut Fatwa Ali Bin Abi Thalib dan Abdullah Bin Mas'ud" Kemenag Lampung, online: 〈https://lampung.kemenag.go.id/files/lampung/file/file/ARTIKEL/Artikel_Rosidin.pdf〉.

18 Ahmad Rofiq, supra note 1.

19 Sayyiq Sabiq, Fiqh sunnah, Fikih Sunnah, 4 (Jakarta: Cakrawala, 2009) at 2.

20 Putri Rosalia Ningrum, "Perceraian Orang Tua dan Penyesuaian Diri Remaja" (2013) 1 E-J Psikol at 74.

${ }^{21}$ Agoes Dariyo, "Memahami Psikologi Perceraian Kehidupan Keluarga" (2004) 2 J Psikol at 94.

22 Rosidin, supra note 17.

23 Amir Syarifuddin, Perkawinan Islam di Indonesia: anatar Fiqh Munakahat dan Undang-Undang Perkawinan (Jakarta: Kencana, 2007) at 303. 
every child must be clear about his nisab. In addition, the iddah period can be used to foster households (referrals) for divorce arising from court decisions. ${ }^{24}$

The iddah period for a woman who is not pregnant and still menstruating is three times quru, or a holy period. If she is not menstruating and is, in fact, pregrant, the length of the day is 90 days while in the pregnancy. Because the iddah period is a condition of a woman who wants to remarry, violation of the iddah requirement will result in the invalidation of any secondary marriage, which fails to satisfy the fundamental requirements for marriage. Legally, any marriage that fails to satisfy marriage requirements must be canceled. In accordance with Article 22 of Law No. 1 of 1974 on Marriage, "marriage can be canceled, if the parties do not meet the requirements for marriage." In the Compilation of Islamic Law marriage cancellation is regulated by two articles: Article 70, which addresses how the first marriage is made legally null and void, and Article 71, which regulates the cancellation of marriage

For a marriage to be canceled, there must be an applicant who submits a request for cancellation to the competent Pangadilan. Parties who can apply for cancellation of marriage are: ${ }^{25}$

1. Families in a straight line upward from husband and wife;

2. An authorized official prior to the officiation of the marriage;

3. An appointed official, as stipulated in Article 16 paragraph (2), and any person who has a direct legal interest in the marriage but after the marriage is terminated (Article 23);

4. In the case of marriage taking place before an Unauthorized Registrarwithout the presence of two witnesses, a cancellation request can be submitted by:

a. Families in a straight line upward from a husband or wife;

b. Husband or wife; and

c. Prosecutor.

5. Anyone who is due to marry is still bound by one of the two parties, yet on the basis of the existence of marriage can propose a new marriage cancellation (Article 24);

6. Marriage cancellation can be carried out by husband or wife if:

a. Marriage is carried out under threats that violate the law (Article 27 paragraph (1));

b. Marriage occurs wrongly regarding the husband or wife (Article 27 paragraph (2)).

Al-Baqarah verse 235 clearly explains that Islam forbids a woman who is still completing iddah of her previous husband to accept proposal or even marry another man, except with an allusion. Scholars also define iddah as the name of time to wait for

\footnotetext{
24 Djamil Latif, Perceraian di Indonesia (Jakarta: Ghalia Indonesia, 1982) at 79.

25 Abdullah Tri Wahyudi, Peradilan Agama di Indonesia (Yogyakarta: Pustaka Pelajar, 2004). at 101-102.
} 
the sanctity of a wife who was left behind by her husband or divorced by her husband. ${ }^{26}$ .$^{27}$ More than pregnancy or sanctity, the purpose of the iddah period is to determine the paternal lineage of the child conceived in the event of pregnancy at the time of divorce. As a result, iddah has an important role in maintaining lineage. Without the iddah obligation, is not possible, in the case of a woman who is married within a few days after parting with her first husband, to determine the father of the child she bore. ${ }^{28}$

Following cancellation, a marriage is considered illegitimate. Husband and wife return to thestatus held prior to marriage. The following are the legal consequences of cancelling or terminating a marriage for husband and wife. First, the relationship between the two is foreign in the sense of having to separate and not look at each other or interact as husband and wife, as would be expected between two people who are foreign. ${ }^{29}$ Second, valid for wives divorced from iddah provisions, as explained below.

Marriage before the end of an iddah period was dealt with in the Decision of the Mojokerto Religious Court Number 1365/Pdt.G/2014/PA.Mr, in which a woman remarried despite still being legally bound by a previous marriage. Legally, someone aware of the incomplete iddah observation should propose the cancellation of marriage in accordance with Article 74 paragraph (1) Compilation of Islamic Law. In the decision, the Petitioner (Head of the Office of Religious Affairs in Jatirejo Subdistrict, Mojokerto) who submitted a request for the cancellation of marriage between Respondent I and Respondent II. Respondent I and Respondent II married on the date of May 24, 2014. The Petitioner felt that the marriage did not meet the legal requirements of a marriage. This is based on the findings of the Islamic Bimas Team of the Ministry of Religion of Mojokerto produced approximately two weeks after the marriage took place on June 4, 2014. It was known that Respondent I was a divorced man whose divorce certificate was issued on September 8, 201l, while Respondent II was a divorced woman whose divorce certificate was issued on April 11, 2014. From the findings, it can be seen that Respondent II did not fulfill the marriage requirements, having not yet completed the iddah period of her first marriage, as explained in Article 40 of the

Compilation of Islamic Law which prohibits a man from marrying with a woman who is still in iddah period of another man. If calculated in accordance with the issuance of the divorce certificate, the iddah period for divorcee is at least 90 days, meaning Respondent II's term would be completed on July 9, 2014. On the basis of Respondent II's standing iddah period, the Applicant is entitled to submit a cancellation application in accordance with Article 23 letter (d) of Law No. 1 of 1974 on Marriage, which states, "the official appointed by the paragraph is in accordance with paragraph

\footnotetext{
26 Amir Nuruddin Azhari Akmal Tarigan, Hukum Perdata Islam di Indonesia Studi Putusan Perkembangan Hukum Islam dan Fikih (Jakarta: Prenada Media, 2004) at 240.

27 Mardani, Hukum Keluarga Islam di Indonesia (Jakarta: Prenada Media, 2016) at 68-69.

28 Muhammad Isna Wahyudi, "Kajian Kritis Ketentuan Waktu Tunggu (Iddah) dalam HMPA Bidang Perkawinan" (2016) at 5.

29 Amir Syarifuddin, Garis-Garis Besar Fiqh (Jakarta: Prenada Media, 2005) at 141.
} 
(2) of Article 16 of this Act and every person who has a direct legal interest in the marriage, but only after the marriage is terminated."

A marriage can be carried out if the marriage conditions are fulfilled completely, including both material and formal requirements. If the marriage does not meet a marriage requirement, the marriage can be canceled. In the Decision of the Mojokerto Religious Court Number 1365/Pdt.G/2014/PA.Mr, an application for marriage cancellation was submitted by the Petitioner. the Head of the Jetirejo Sub-District Religious Affairs Office, Mojokerto Regency. The Petitioner argues that the marriage does not meet marriage requirements specified by law and is prohibited according to Islam. The marriage between Respondents I and II was held on May 23, 2014. Before the marriage was carried out between the Respondents, it was known that both Respondents were divorced, but there were no barriers or closer examination of the status from either Respondent, family and witnesses, or marriage registration staff. On June 5, 2014 in accordance with Article 74 paragraph (1) Compilation of Islamic Law, the Petitioner submitted his application to the competent court.

Failure to prevent marriage from occurring when it does not meet the established requirements creates future legal problems. It was known after two weeks of marriage that some marriage requirements were not fulfilled, leading to a prohibition to carry out a marriage obtained from the findings by the Islamic Bimas Team of the Ministry of Religion of Mojokerto Regency on June 4, 2014. After being examined, it was discovered that Respondent II was divorced before the marriage took place, documented in Divorce Deed Number 0828/AC/2014/PA.Mr on April 11, 2014. The Islamic Bimas Team's findings were used as an excuse by the Petitioner to submit a request for the cancellation of the Respondents' marriage. It is known that the distance between the divorce of Respondent II's first marriage and the occasion of the second marriage was approximately 15 days, while the iddah period for a divorcee is at least 90 days. ${ }^{30}$ Therefore, if a marriage is carried out before the iddah period is completed, the marriage can be canceled in accordance with Article 71 letter (c) Compilation of Islamic Law.

Since Respondent II did not complete the iddah period, a potential pregnancy at the time of her remarriage would be affected by unclear paternity. ${ }^{31}$ The cancellation of marriage between Respondents I and II was motivated by the desire to ensure that any potential child would know who their father is. However, in the court's decision it was not stated that Respondent II was or was not pregnant. Therefore the cancellation of marriage is useful to determine whether or not Respondent II is pregnant. When marriage, such as that carried out by the Respondents, is canceled, the marriage is deemed to have never existed in accordance with the definition of "cancellation" in the Large Indonesian Dictionary which means invalid orassumed to never have existed. To ensure that Respondent I and Respondent II obeyed the decision, the legal consequences for the Respondents were to return to their premarital. Respondent I

\footnotetext{
30 Amir Syarifuddin, supra note 29 at 310.

31 Al-Junnatul Ali, Al-Quran dan Terjemahannya (Bandung: Penerbit J-Art, 2005) Article 235.
} 
again became a divorced man with certificate number 1280/AC/2011 /PA.Ngj, and Respondent II's status returned divorcee according to divorce certificate Number 0828/ AC/2014/PA.Mr.

In the Islamic tradition, cases of canceled marriages also carry the consequence of iddahfor women. In the opinion of Sa'id bin al-Musayyab and Sulauman bin Yasar, the marriage of a husband and wife is separated so that the iddah period will be applied. ${ }^{32}$ The iddah period that must be undertaken by Respondent II is twice in length, encompassing iddah for divorce with Certificate Number 0828/AC/2014/PA.Mr and the second iddah period from the newly married husband, Respondent I. There are exceptions to the iddah period; if Respondent II has not engaged in intercouse with Respondent I, then only one iddah is required for Respondent II, that which applies to the first marriage terminated by divorce. However, the marriage between Respondents I and II was already two weeks old. As the Respondents were able to consummate their marriage, Respondent II must undergo two iddah periods for the first terminated marriage and second canceled marriage.

After Respondent II has finished passing the iddah period of the divorced marriage and canceled marriage, is it permissible for Respondents I and II to remarry? According to Abu Hanifah, Imam Shafi'i, and al-Tsauri, ${ }^{33}$ it is permissible for widows whose marriages are canceled to return home as long as each party wishes to be permitted but on condition that they must implement a new marriage certificate. Respondent I and Respondent II, whose marriage was canceled, can return and remarry as long as each of them wishes to do so and can satisfy the conditions of a new contract. On the other hand, the opinions of Imam Maliki, al-Auza'i, and al-Laits suggest that a husband and wife whose marriage is canceled are forbidden to remarry ever again, regardless of whether or not they wish to do so. ${ }^{34}$ Despite this argument, Abu Hanifah, Imam Shafi'i, and al-Tsauri argued that marriage is a right for everyone. ${ }^{35}$ As stated in the Indonesian Constitution, namely the 1945 Constitution of the Republic of Indonesia Article $28 \mathrm{~B}$, "everyone has the right to form a family and to continue the descent through legal marriage." Article 10 of Law No. 39 of 1999 concerning Human Rights likewise supports the right to marry. Many scholars now use the opinions of Abu Hanifah, Imam Shafi'i, and al-Tsauri who, defending the couple whose marriage was cancelled because completion of the required iddah period satisfies that requirements that were originally unfulfilled. .

Regarding the assets in marriage cancellation, there is still a division of assets which also involves third parties, although the Court's decision is not explicitly stated. This division of assets is carried out as long as each party has good intentions. Goodwill assumes that at the time of the marriage the Respondents did not have an intentional element to carry out the marriage by not fulfilling these conditions. The distribution is

\footnotetext{
Mardani, supra note 27.

Ibid.

Ibid.

35 Ibid.
} 
done according to the provisions of the marriage agreement. For those without a marriage agreement, the distribution of property is done equally between the Temohon. In the case of a third party, court decisions do not apply retroactively. If there is a legal action that results in a third party's procurement of an asset, the procurement must be fulfilled according to the agreement made.

\section{THE CONSEQUENCES OF MARRIAGE CANCELLATION WITH RESPECT TO CHILDREN}

The effect of the marriage cancellation, stipulated in Law Number 1 of 1974 on Marriage, is as follows: (a) that the cancellation of a marriage begins after the decision of the court, has permanent legal force, and is valid from the time the marriage takes place; (b) decisions do not apply retroactively to; (c) children born from the marriage; (d) husbands and wives who act in good faith, not including joint assets, if the cancellation of marriage is based on the existence of another marriage in advance; and (e) other persons not included in a and b as long as they obtain rights in good faith beforehand regarding the permanent legal force of cancellation.

Other consequences of marriages that are canceled other than the husband and wife are the result of the child born from the marriage Other than the husband and wife, the consequences of marriage cancellation impact children born of the canceled marriage. Legal consequences forthe child born of the marriage between Respondents I and II did not apply at the time of cancellation, because the age of the marriage was approximately two weeks, and it was unknown whether Respondent II was pregnant. If, for example, one day later it is known that she is pregnant, the gestational age must be calculated so as to discern whether Respondent II is carrying the child of Respondent I or the previous husband.. If Respondent II is pregnant by Respondent I, the child is a legitimate child of the canceled marriage. Respondent I and Respondent II would be legitimate parents even though the marriage was been canceled. Parents have the obligation to give rights to children from marriages that are canceled until the child is married. Rights include those as the heirs of the father, acting as guardians of the marriage if the child is a woman, and providing affection to the child in general.

\section{COURT'S CONSIDERATIONS}

The decision of the Mojokerto Religious Court number 1365/Pdt.G/2014/PA.Mr, is a constitutive decision, or a decision that creates a new legal condition. In this case, a legal situationwas created between the husband and wife whose marriage was canceled; the marriage was considered to never have existed and both parties returned to their premarital status. The marriage cancellation request submitted by the Petitioner (Head of the Office of Religious Affairs in Jatirejo Subdistrict, Mojokerto Regency) claimed that marriage between Respondent I and Respondent II is legally flawed because it did not meet requirements set forth by established marriage laws, 
especiallyArticle 71 Compilation of Islamic Law. The Petitioner submitted amarriage cancellation application on June 5, 2014 to the clerk of the Mojokerto Religious Court with case number 1365/Pdt.G/2014/PA.Mr. A marriage that is to be approved should be examined by officers from the relevant Office of Religious Affairs;however, negligence and inaction of Religious Affairs Office staff in examining fulfillment of marriage requirements left legal issues with the Respondents' marriage unnoticed until two weeks after the marriage took place.

The parties in the case of the Mojokerto Religious Court Decision number 1365 / Pdt.G / 2014 / PA.Mr are as follows:

a. The applicant, Head of the Office of Religious Affairs in Jatirejo Subdistrict, Mojokerto Regency;

b. Respondent I, husband;

c. Respondent II, wife.

In the case number 1365/Pdt.G/2014/PA.Mr led by Dr. Asfa'at Bisri as Chief Judge, Dr. H. Moh. Fadli, S.H., MA as Member Judge I and Ali Hamdi, S.Ag. as member judge II. the Hakum Assembly decided based on the results of the examination and several considerations were made by the Judge himself. The judge first attempted mediation between the Petitioner and the Respondents, but was ultimately unsuccessful. The Petitioner remained committed to the pursuit and claims of his petition. The Respondents also confirmed the statement of the Petitioner's petition and did not mindmarriage cancellation. After the evidence from the Applicant is examined, then it is followed by examination of witnesses related to the case. From the testimonies of the witnesses, made before trial and under oath, witnesses confirmed:

1. That Defendant I and Defendant II held a marriage on May 23, 2014 and listed the marriage at the marriage registrar's office, or the Office of Religious Affairs in Jatirejo District, Mojokerto Regency;

2. After the marriage was registered, Respondent I and Respondent II stayed at the Respondent's parents' house for 2 weeks until there were findings from the Islamic Bimas Team of the Ministry of Religion, Mojokerto Regency;

3. That the witnesses only learned from the findings of the Islamic Bimas Team of the Ministry of Religion of Mojokerto Regency that Respondent II was still in the iddah period and was not allowed to marry another man;

4. Witnesses admitted that they were not careful in examining the marriage requirements of Respondent I and Respondent II.

From the conclusions of the testimonies of the witnesses it can be concluded that the marriage carried out by Respondent I and Respondent II did not meet the marriage requirements.. The marriage was able to proceed because the Respondents and witnesses failed to thoroughly review or disclose their fulfillment of conditions, while the employees of the Office of Religious Affairs were not careful in examining the case prior to listing and registration.If the marriage is not canceled, it is feared that there will be no way to distinguish between the offspring of Respondent II's previous 
husband and Respondent I, should she become pregnant. Therefore the Panel of Judges granted the request by giving a verdict on case number 1365/Pdt.G/2014/PA.Mr on Friday, July 25, 2014, making the following decisions:

1. To grant the Petitioner's petition;

2. Cancel the marriage of Respondent I and Respondent II held at the Office of Religious Affairs (KUA) in Jatirejo Sub-District, Mojokerto Regency held on May 23, 2014;

3. Declare the Quote of the Marriage Deed Number: 0187/049/V/2014 dated May 23, 2014 issued by the Office of Religious Affairs in Jatirejo SubDistrict, Mojokerto Regency, without legal standing;

4. Charge the Applicant to pay the court fee in the amount of Rp. 346,000 (three hundred forty six thousand rupiahs).

To discern whether the Judge's legal considerations are in accordance with the provisions in Law No. 1 of 1974 on Marriage, Presidential Instruction No. 1 of 1991 on Compilation of Islamic Law and Government Ordinance No. 9 of 1975 on Implementation of Law Number 1 of 1974 on Marriage, the author will describe the matters that are considered by the Panel of Judges, including:

1. Authority of the Mojokerto Religious Court

The court's authority is legally grounded in Article 25 of Law No. 1 of 1974 on Marriage and Article 37 Government Regulation No. 9 of 1975 concerning Implementation of Law Number 1 of 1974 on Marriage. Article 74 Compilation of Islamic Law likewise states that an application for the annulment of marriage is submitted to the District Court where the implementation of the marriage is carried out or the place of residence of both husband and wife. The Mojokerto Religious Court can examine and hear cases of cancellation of marriage between the Respondents in which the residence of both parties falls within in the jurisdiction of the Mojokerto Religious Court in Jatirejo District, Mojokerto Regency.

2. Authority of the Applicant In the trial the Judge will examine and assess the person who submitted the request for the annulment of the marriage to determine whether or not he has the right to submit a marriage cancellation request. In Law No. 1 of 1974 on Marriage is contained in Article 23 letter (d) Jo. Compilation of Islamic Law on Article 73 letter (d) Jo. Article 2 paragraph (1) and (2) Regulation of the Minister of Religion No. 11 of 2007 which states that those who can apply for marriage cancellation are:

a. Families in a straight line upward from a husband or wife

b. Husband or wife

c. Authorized officials connected to the case when the marriage has not yet been officiated, and

d. The appointed official and anyone with a direct legal interest in the marriage, but only after the marriage is broken. 
The Petitioner in case Number 1365/Pdt.G/2014/PA.Mr which is the official appointed as VAT, the Head of the Office of Religious Affairs in Jatirejo Subdistrict, Mojokerto Regency has the right as the Petitioner to submit a request for the annulment of the marriage of theRespondents' marriage.

3. Reasons for the marriage cancellation request In the case Number 1365/Pdt.G/2014/PA the reason for the cancellation of marriage by the Petitioner originated from the findings of the Islamic Bimas Team of the Ministry of Religion in Mojokerto Regency on June 4, 2014. It was discovered that Respondent II had not yet completed her iddah period and may not yet be married to another man. It is known in laws and regulations that widows who are in a iddah period of marriage are not permitted to marry. Articles 9 and 11 of Law No. 1 of 1974 on Marriage state that a person who is still married or has not yet fulfilled the conditions of their marriage termination is unable to remarry and women of marriages terminated by divorce must complete an iddah period.

4. Prohibition of marriage One requirement of marriage is the absence of marriage prohibitions on behalf of either prospective spouse. A prohibition is an absolute requirement that must be fulfilled, as regulated byArticle 40 Compilation of Islamic Law which states that it is prohibited to hold a marriage between a man and a woman because of certain conditions:

a. Because the woman in question is still observing iddah from a previous marriage;

b. A woman who is still in the middle of a period with another man;

c. A woman who is not Muslim.

This decision the prohibition on marriage is found in RespondentII, where Respondent II was still in the iddah of the termination of the previous marriage, namely 3 times the holy period or at least 90 days. In this decision, the extant prohibition is Respondent II's unfulfilled iddah period from a previous marriage. The outstanding prohibition means that is forbidden to marry another man without completing the iddah of her first marriage, as stated in Article 40 letter (b) Compilation of Islamic Law.

5. Judges' opinions In decision number 1365 / Pdt.G / 2014 / PA.Mr. the Panel of Judges agreed that the marriage did not fulfill the marriage requirements established by law. In the hearing it was acknowledged that Respondent II was still observing iddah from her previous marriage, as illustrated by the Petitioner's evidence, specifically Divorce Deed Number 0828 / AC / 2014 / PA.Mr dated April 11, 2014 and issued by the clerk of the Mojokerto Religious Court. Thus the marriage of Respondent II and Respondent I could be canceled on the basis of Law No. 1 of 1974 on Marriage Article 22. Compilation of Islamic Law Article 71 letter (c) states that any marriage held in the period 
of iddah inherently does not fulfill legal marriage requirement. The Panel of Judges granted the Petitioner's cancellation petition on the basis of this law, as well as the word of Allah in the Al-Qur'an verse 228 Surat Al-Baqarah, which states:"women who are accused should refrain (wait) three times holy." (Q.S. Al-Baqarah: 228),"and the arguments contained in the book I'natuth Tholibin Jus II page 280, which read:

"And the conditions for prospective wives or women who are married include not being married to other people, not in bondage with iddah from other men and so on".

\section{CONCLUSION}

Based on the results of the study, several conclusions can be made. First, if a woman remarries before the iddah period is finished, the marriage must be canceled. This is because the marriage does not meet all of the requirements of a good marriage set forth by marriage law, customary law, and Islamic law . After the marriage is canceled, the consequences that arise for husband and wife are such that both return to their premarital status and cease any sort of relationship As for the wife, she must continue her original iddah as well as a secondary iddah for the marriage that has just been canceled if the secondary marriage was consummated. After undergoing two periods of iddah, she should be able to resume marriage with the new aqad, based on the opinions of Abu Hanafi and al-Tsauri.

Second, judicial legal considerations in deciding cases of cancellation due to incomplete iddah are rooted in several laws. In their legal considerations, the Judges stated that the marriage between the Defendant I and Defendant II did not fulfill the marriage requirements, because Defendant II was still observing tge iddah period of her previous marriage, and should therefore complete her iddah as an unmarried woman for the full 90 day term, as stated in Article 153 paragraph (2) letter (b) of the Compilation of Islamic Law. This argument was alsoused as a reasonable excuse for the Petitioner to submit a permit for cancellation.. The legal basis used by the Panel of Judges to grant the request for the cancellation of marriage between Respondents I and II was effective because it hwas proved that the marriage did not meet marriage requirements established by Article 22 of Law No. 1 of 1974 on Marriage and Article 71 of the Compilation of Islamic Law. On the same basis, cancellation petition should be granted, such that the marriage between Respondent I and Respondent II is declared null and void.

Several suggestions can be made as a result of this study. First, in the process of registering and officiating a marriage, prospective spouses should know the marital and prohibition status of their potential partner. They should ensure that each partner's status complies with all laws concerned with marital conditions and that no prohibitions exist which could result in the prevention or cancellation of marriage. Then employees of the Office of Religious Affairs (KUA) for Muslims, they are required 
to be more careful in checking the identity and requirements of the parties who will register a marriage, such that in the future there will be no legal problems arising from the marriage. Second, the government, community institutions, and community leaders should pay attention to issues concerning matters related to marriage by facilitating socialization on matters relating to marriage such as the consequences of marriage, the consequences of breaking up marriage, and marriage restrictions. Especially regarding the period of iddah in Islam, of which there are several kinds, which applies specifically to potential causes for the cancellationof a marriage and consequences faced by women. Socialization is very necessary so that people can know all the requirements and restrictionsof marriage. Third, in making decisions the Judges can also consider Article 40 of the Compilation of Islamic Law because in this case, one of the reasons for the request for cancellation was the non-fulfillment of marital conditions. In the decisionthe court should also mention the additional iddah incurred by Respondent II due to the cancellation of her second marriage.

\section{REFERENCES}

Abd Rahman Ghazaly. Fiqh Munakahat (Jakarta: Prenada Media, 2003).

Abdulkadir Muhammad. Hukum Perdata Indonesia (Bandung: Citra Aditya Bakti, 2000).

Abdullah Tri Wahyudi. Peradilan Agama di Indonesia (Yogyakarta: Pustaka Pelajar, 2004).

Ahmad Azhar Basyir. Hukum Perkawinan Islam (Yogyakarta: UII Press, 1990).

Ahmad Rofiq. Hukum Perdata Islam di Indonesia (Jakarta: Rajawali Persada, 2015).

Ahmad Rofiq. Hukum Perdata Islam di Indonesia (Jakart: Jajawali Persada, 2015).

Al-Junnatul Ali. Al-Quran dan Terjemahannya (Bandung: Penerbit J-Art, 2005).

Amir Syarifuddin. Garis-Garis Besar Fiqh (Jakarta: Prenada Media, 2005).

- - - Perkawinan Islam di Indonesia: anatar Fiqh Munakahat dan Undang-Undang Perkawinan (Jakarta: Kencana, 2007).

Azhari Akmal Tarigan, Amir Nuruddin. Hukum Perdata Islam di Indonesia Studi Putusan Perkembangan Hukum Islam dan Fikih (Jakarta: Prenada Media, 2004).

Djamil Latif. Perceraian di Indonesia (Jakarta: Ghalia Indonesia, 1982).

Lili Rasjidi. Perkawinan dan Perceraian di Malaysia dan Indonesia (Bandung: Remaja Posdakarya, 1992).

Mardani. Hukum Keluarga Islam di Indonesia (Jakarta: Prenada Media, 2016).

Mohammad Idris Ramulyo. Hukum Perkawinan Islam, Suatu Analisis UU No.l Tahun 1974 dan Kompilasi Hukum Islam (Jakarta: Bumi Aksara, 1996).

Sayuti Thalib. Huku Kekeluargaan Indonesia (Jakarta: Rajagrafindo, 2000).

Sayyiq Sabiq. Fiqh sunnah, Fikih Sunnah, 4 (Jakarta: Cakrawala, 2009).

Agoes Dariyo. "Memahami Psikologi Perceraian Kehidupan Keluarga” (2004) 2 J Psikol.

Putri Rosalia Ningrum. "Perceraian Orang Tua dan Penyesuaian Diri Remaja" (2013) 1 E-J Psikol. 
Rosidin. "Masa Iddah Wanita Hamil yang Ditinggal Wafat Suaminya Menurut Fatwa Ali Bin Abi Thalib dan Abdullah Bin Mas'ud" Kemenag Lampung, online: 〈https://lampung.kemenag.go.id/files/lampung/file/file/ARTIKEL/Artikel_Rosidi n.pdf $>$.

Wibowo T Tunardi. "Syarat-Syarat Sahnya Suatu Perkawinan”, (3 May 2019), online: J Huk 〈http://www.jurnalhukum.com/syarat-syarat-sahnya-suatu-perkawinan/〉.

"Syarat-Syarat Perkawinan", (3 May 2019), online: Syarat-Syarat Perkawinan 〈http://pkbh.uad.ac.id/syarat-syarat-perkawinan/〉. 
252 | The Iddah Period as a Reason for Cancellation of Marriage

This page is intentionally left blank 